\title{
Creative Imagination and its Development in Ontogenesis
}

\author{
Valerijs Makarevics ${ }^{1}$ Dr. psych.; Dzintra Ilisko ${ }^{2}$ Dr. paed. \\ Daugavpils University, Latvia \\ valerijs.makarevics@du.lv ${ }^{1}$; dzintra.ilisko@du.lv ${ }^{2}$
}

\begin{abstract}
Education for sustainability comprises knowledge about the ontogenetic tendencies of development of creative imagination, because creative imagination is necessary for implementing programs of sustainable education. On the turn of the $20^{\text {th }}$ century $\mathrm{T}$. Ribot has carried out the research on age peculiarities of creative imagination. It was stated in the research that creative imagination is developed most intensively in the preschool and at the early school age. Further on, the development of creative imagination slows down and declines at the age of adolescence. The aim of this investigation is a comparison of ontogenetic tendencies of a development of creative imagination during times of T. Ribot and our peers. The experiment of the research of ontogenetic peculiarities of creative imagination included in itself two parts. During the first part in 1995-2000 two hundred participants took part in this experiment. During the second part in year 2016 one hundred participants took part. The modification of the test of E.P. Torrance took place and the results gained in this test were similar to the results gained in the test by T. Ribot. It was discovered that during the development of creative imagination there are two crises: during the age of 7-8 and during the age of 15-16. Results gained during this research leads to conclude there are two peaks in the development of an individual (at the age group of 11-12 and at the age of 30-40). The results are statistically significant.
\end{abstract}

Keywords: sustainable education, Ribot, creative imagination, development of creativity.

\section{Introduction}

Creativity has been absent from the sustainable development agenda despite its importance in developing the freedom of expression and dialogue. Creativity is an open-ended concept. Today creativity has become a source of entrepreneurial inspiration and a drive to innovation. The task of today is to root it in sustainable social-economic and environmental practices. Creativity contributed to attaining the ideals of sustainable society by encouraging an autonomous thinking, by seeking inventive and innovative aspects as a part of any development strategy oriented towards fostering sustainable development (Shlahova, Volonte, Cacka, 2017; Ilisko, 2007; Salite, 2015). Creativity is a dynamic and evolutionary concept since new problems arise. It also has a practical side since it makes one to move from thought to action or from a dream to decision. Creation implies creating new ways to look at the issue or a task, and sometimes in unexpected ways.

One of the first researchers who studied the issue of a creative imagination, is the creator and the director of the first French laboratory of an experimental psychology, Theodul Ribot (1839-1916) in his works wrote about the importance of creative imagination in the development of both an individual and all the humankind. In his work "Creative Imagination," by referring to Vico's research, he wrote that the history of a humankind can be divided into three stages. The first stage can be called divine, or theocratic. The second - heroic, or fabulous. The third is historical, or human. In the first two stages, as T. Ribot wrote, that the imagination dominates (in the third it is gradually replaced by the logical thinking). It was the imagination of people who created myths, religions, legends, sagas and epics. Moreover, the author further points out, that a holistic development of peoples and cultures implies a compulsory passage through these two first stages (Ribot, 1906). Having determined the historical significance of the creative imagination, Theodor Ribot organizes an experimental study about the age-specific features of the development of person's mental process. As a result of the research, it was concluded that a creative imagination is intensively developing at the junior school age. The critical point of development of the phenomenon is when the progressive trends are replaced by the regressive ones and coincides with the onset of adolescence. The results of the T. Ribot's study are schematically seen in Figure 1.

In line with the results gained during the experiment of $\mathrm{T}$. Ribot, the development of creative imagination is more intense during the age group of 5-15, followed by a regression. Since T. Ribot has carried out his experiments, one hundred years passed since then. Since then a number of innovation have been introduced such as radio, television, internet and mobile connections. In this context the 
question should be set how all those innovations have influenced a creative imagination of a person or how the experiment set by the T. Ribot relates to a contemporary situation.

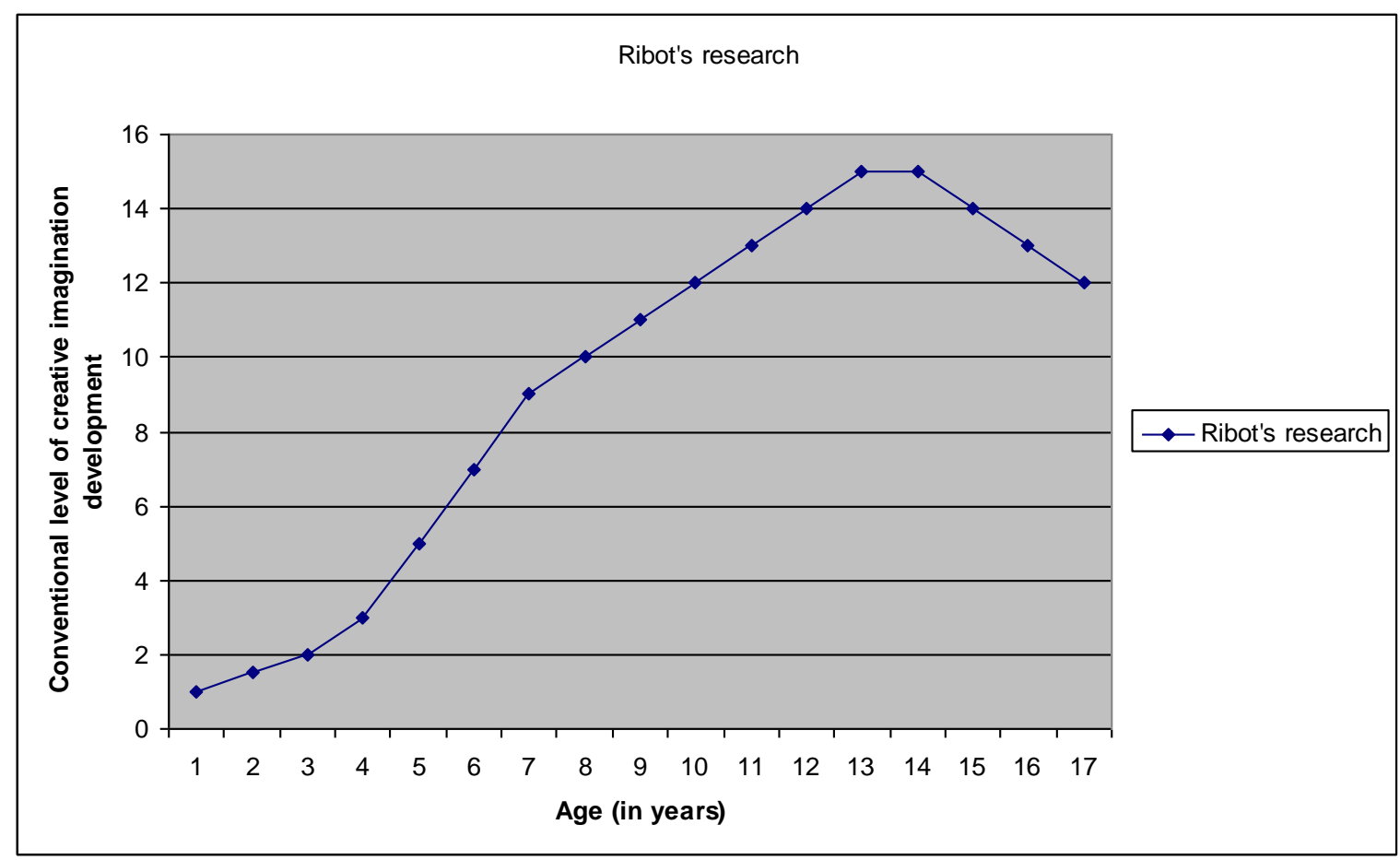

Figure 1. T. Ribot's curve showing the dynamics of the development of creative imagination.

The research of creative imagination includes in itself three parts: Philosophically psychological that focuses on the understanding of the main notions; the understanding of a notion of creativity, learning the place of creativity in the structure of psychological processes of a personality. There were two strong conceptions among all the philosophical and psychological concepts. One was related to the philosophy of positivism. The second is psychoanalytical.

The author of the first concept D. Dewey defines creative imagination as an act of thinking. This is necessary in the case when finding a solution from the situation, one learns about the result first before the solution is derived by the operations of logical thinking (Dewey, 1910). Here creative imagination is a process that supports logical thinking. The conception of D. Dewey explains one of the creative parts of an individual, namely, technical creativity.

The representatives of psychoanalysis do not come to an agreement about the definition of creative imagination. For example, Z. Freud considers creative imagination as the bases of creativity that arises as a result of sublimation, by transforming sexual energy for the socially significant aims (Freud, 1990, 2011). For the C.G. Jung and his followers, creative imagination and creativity is related to the actualization of deep psychic notions - archetypes (Jung, 1988). Those notions are related to the use of creative imagination to the development of a person. Here it should be noted that the subject of psychoanalytic concepts is artistic creativity.

This is necessary to emphasize that the main notion of the psychoanalytical conceptions are notions. Now we will explore the issue of a notion. V.P. Gloveanu in his research: „Creativity in context: the ecology of creativity evaluations and practices in an artistic craft" has formulated two questions the answers to which allows to understand the meaning of creativity.

The first question is: "How can creativity be defined?" The second question is: "Where is creativity located?" While answering the first question, the author distinguishes two-time frames that differ with the focus of attention on a creative person. The first period can be described by its focus on a creative activity of great personalities. The second period has started in the middle of the last century and lasted until the 20th century with its focus on creativity of ordinary people (Gloveanu, 2010). V.P. Gloveanu describes creativity as a tirade "creator-society-new creation." Creativity comprises individual peculiarities of a creator and social requirements set for the creative product. Creative imagination in this structure reflects individual peculiarities of a person (Gloveanu, 2010). 
Researchers have come across the same understanding that a creation of something new depends on one's motivation and creativity (Amabile, 1996). Creativity is reflected in ingenuity, inspiration, serendipity and talent (Plucker, Makel, 2010).

The theories of creativity use the criteria that were set for describing the act of creativity. Before we reflect on theories of creativity we need to point out that in the Eastern European languages. One can find two understandings of creativity reflecting both, the process and the outcome of a creative process. In the Latvian language it is translated as "radosums" - "jaunrade." In the Polish language:

"kreatywnosci - kreatywnosc", the Estonian language: "loovust - loovus."

Since there is no such division of this term in English, therefore many processes cannot be explained in a very detailed way. For example, the text in Russian, which is given below and in which the author compares the concepts of creativity (tvorchestvo-process) and creativity (kreativmost, result): Creativity (tvorchestvo) is primary and fundamental. Creativity (kreativnost) is secondary. Creativity (kreativnost) is based on creativity (tvorchestvo) and cannot exist without it cannot be translated into English.

This makes the process of creative activity more difficult for the translation and interpreting as it is explained in the Eastern European literature sources. All the theories of creativity can be divided in two groups. The theories of the first groups can be defined as typological. The theories comprising the second group can be named as structural.

Typological theories describe different aspects and spheres of creativity. The theory of 4P, distinguishes the following spheres: a process, a product, personality and a place (Kozbelt, Beghetto, Runco, 2010; Rhodes, 1961). This process involves skills that are needed for completing the task. The product can be evaluated according to the following criteria that are used for the evaluation of a creative work. Creative personality can be defined by peculiarities of thinking, imagination and motivation that allow to design a creative outcome. Finally, special social conditions are needed that lead to a creative outcome (product).

Psychological literature offers typological theories of creativity. The authors of a collection of articles "The Nature of Creativity Contemporary Psychological Perspectives" (Sternberg, 1988) describe not only spheres of creativity but the interrelatedness of environment and a personality. Theories that are focusing on the process of creativity in a single sphere can be named as structural. Research of a process of creativity as a rule is related to one of the spheres of intellect.

The other sphere of creativity is related to the product of a creative activity. The Latvian researcher D. Kaleja-Gasparovica has come to a conclusion that creativity of the product of a creative activity can be described according to the following criteria:

- originality, innovation that can be observed in a certain context: individual social and universal;

- value (efficiency, acceptance);

- elegance (aesthetical quality);

- transferability (idea can be used in other situations and contexts);

- intentionality (Kaleja-Gasparovica, 2012).

The third sphere is related to a personality. Creativity is reflected as originality in thinking (Alexander, Shoshani, 2015). Creativity begins with an idea. M.A Boden (2004) maintains that creativity is something of a mystery, not to say a paradox. By this the author emphasizes that creativity is related to an intuition and logical thinking (Boden, 2004).

Creativity is frequently being related with originality. S. Acar, C. Burnett, J.F. Cabra relate creativity to a dimension of a value, surprise and aesthetics (Acar, Burnett, Cabra, 2017). The fourth sphere related to creativity, is an environment. Social sphere initiates creation of new ideas in different spheres of human life. Another line of research related the issue of creativity is the role and the place of creative imagination in the structure of psychical processes of the personality. Plesk distinguishes the following components of a creative personality:

- purposeful analyses;

- generation of ides and critical evaluation of ideas.

According to P.E. Plesk, creative process from its very beginning (creation of an idea) is related to thinking and imagination. Still, the central process is a creative imagination (Plesk, 1997). 
Several other researchers point to the main role of creative imagination in the process of creativity. The researcher A.J. Starko offers the following structure of creativity:

- thinking in metaphorical terms;

- flexibility and ability to make decisions;

- resistance to a pressure;

- interest in the innovations;

- ability to think logically;

- ability to visualize;

- ability to think outside the box (Starko, 1995).

Creativity is related to thinking. In the first case - metaphorical, in the second - logical. In this context, metaphorical thinking is synonymous of a creative imagination.

Research published in English reflects the following terminology. The term 'creative imagination' is being replaced by the term 'creative thinking.' There are certain contradictions.

L.I. Shragina explains that creative imagination and creative thinking has a common ground and similar mechanism of activity, but both have different aims: thinking is oriented towards the analyses of the surrounding reality, but imagination is related to a creation of new images (Shragina, 2013).

In the light of the results of the development of a creative imagination reflected above and by taking into account the peculiarities of a development of psychic processes of a contemporary person, the authors formulated the hypotheses of the research in the following way: creative imagination development in its ontogenesis has a non-linear character while both progressive and regressive tendencies are observed in the process of a development.

To test the hypotheses, the authors set the following tasks:

- to explore diverse theories of a creative development and a creative imagination (this was disclosed in the introduction);

- to select the methodic for testing creative imagination (this issue was disclosed in the part of methodology);

- to explore the tendencies of development of a creative imagination in ontogenesis;

- to carry out research by testing results gained during the study and to compare them with the results gained by T. Ribot (these tasks will be solved in the section Results and Discussion).

The aim of the study: To explore ontogenetically peculiarities of the development of a creative imagination among our peers and to compare results with the conclusions of T. Ribot.

\section{Methodology}

The choice of a methodology is related to two significant aspects. First of all, the participants of this research were the respondents comprising diverse age groups. Secondly, the result of research was measured in a quantitative term in order to be compared.

These were the criteria set by E.P. Torrance in order to measure the level of creativity of a person: TTCT (Torrance Tests of Creative Thinking) (Torrance, 1966). For the purpose of this research the authors have used two modified subtests. With the help of first sub-test the authors have studied nonverbal aspects of a creative imagination. This subtest was comprised of 16 unfinished drawings which a respondent was asked to complete (Figure 2).

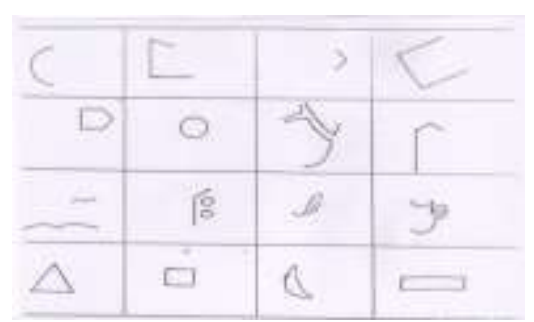

Figure 2. Subtest which allows studying the nonverbal constituent of creative imagination. 
Each drawing is evaluated in one-point score. The authors set the criteria used for the evaluation of drawings. The drawing is not completed. The author uses the idea suggested in the drawing. The respondents use only one element for completing the drawing: 0 points. The author uses his/her own idea while completing a drawing. The respondent uses several elements while completing a drawing: 1 point. One can notice a development of a plot. The lines in a drawing became a part of a plot. The lines offered in the drawing can be seen in a drawing: 2 points. The lines offered at the beginning of activity cannot be seen. The lines are integrated in the drawing and are connected with other details: 3 points.

In Figure 3 one can see the example of drawings placed in the upper line of the stimulus material.

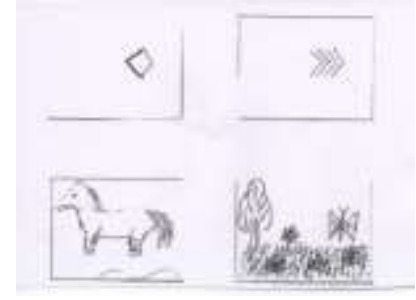

Figure 3. Additions to the drawings evaluated in 0, 1, 2, 3-point scale.

The second subtest allowed to learn about a verbal aspect of a creative imagination. The representatives of all age groups were offered the following task to complete: they were asked to think about as many words as possible for a description of objects with the following characteristics: white, small, round, edible. If word is being repeated by three and more respondents from the same age group, the respondent gets 0 points. If a word is not repeated three times by the other research participants, one gets 2 points. The results on a nonverbal and verbal aspects of the test were summarized afterwards after a completion of the test.

The number of respondents who took part in this research were 300 respondents comprising the age group from 5-40. All the respondents were divided in 13 age groups: 5, 6, 7, 8, 9-10, 11-12, 13-14, $15-16,17-18,19-20,21-24,25-28,29$ and up years old. The experiment on ontogenetic peculiarities of creative imagination consisted of two parts. The first part took place in 1995-2000 and 200 people took part in this experiment. During the first part of the experiment there were 15 participants, including 6-7 years old (20) and 5 years old (10) participants. During the second part of the experiment that took place in groups pf 6, 7 and 8 years old children (20 participants in each group), as well as 15-16 and 17-18 years old pupils in every group. The aim of the 2nd part of the experiment was: checking up results gained during the first part of the experiment. The sample was composed on the bases of the following participants: pupils of the comprehensive school, adults with the educational level lower than average. The sample was made according the principle of occasional choice of the sample. The participants were inhabitants from Daugavpils and Ilukste (South-East Latvia).

\section{Results and Discussion}

Figure 4 depicts the average a level of development of verbal and nonverbal development of creative imagination depending on the age group. Figure 4 reflects that for children of age 8 there is an evolution of creative imagination. At the age of 14, the process of development on creative imagination is more intense until recession begins.

At the age of 20, one can notice the raise of creative imagination. The dynamic of a creative imagination that is reflected in the figure 4 , repeat the tendencies that were discovered by $\mathrm{T}$. Ribot. The plot appeared in drawings of children aged 8. The drawings were the respondents could gain the highest score are similar to the drawings done by the children at the age of 11 .

By the use of the Student's T-criteria, the author has calculated a statistical significance of level of development of creative imagination. The age of different age groups indicates that the most significant changes in measurements (the level of significance -0.01) takes place at the age of $8(3,422)$, and 14 $(7,092)$, as well as at the age of $20(3,523)$. There are three critical points in the process of ontogenetic development of a creative imagination. Two of them are related to a transition to the stage of progressive changes - one is related to a transition to significant negative tendencies in the development of creative imagination. At the age of 7-8, one can notice a delay in a dynamic of a development of a level of creative imagination. This can be explained by the changes in the dominant behavior. Children begin 
attending the school at the age of seven. The child needs to adapt to a new environment, particularly a narrative position of a school pupil. The child needs to respond as this as required at school.

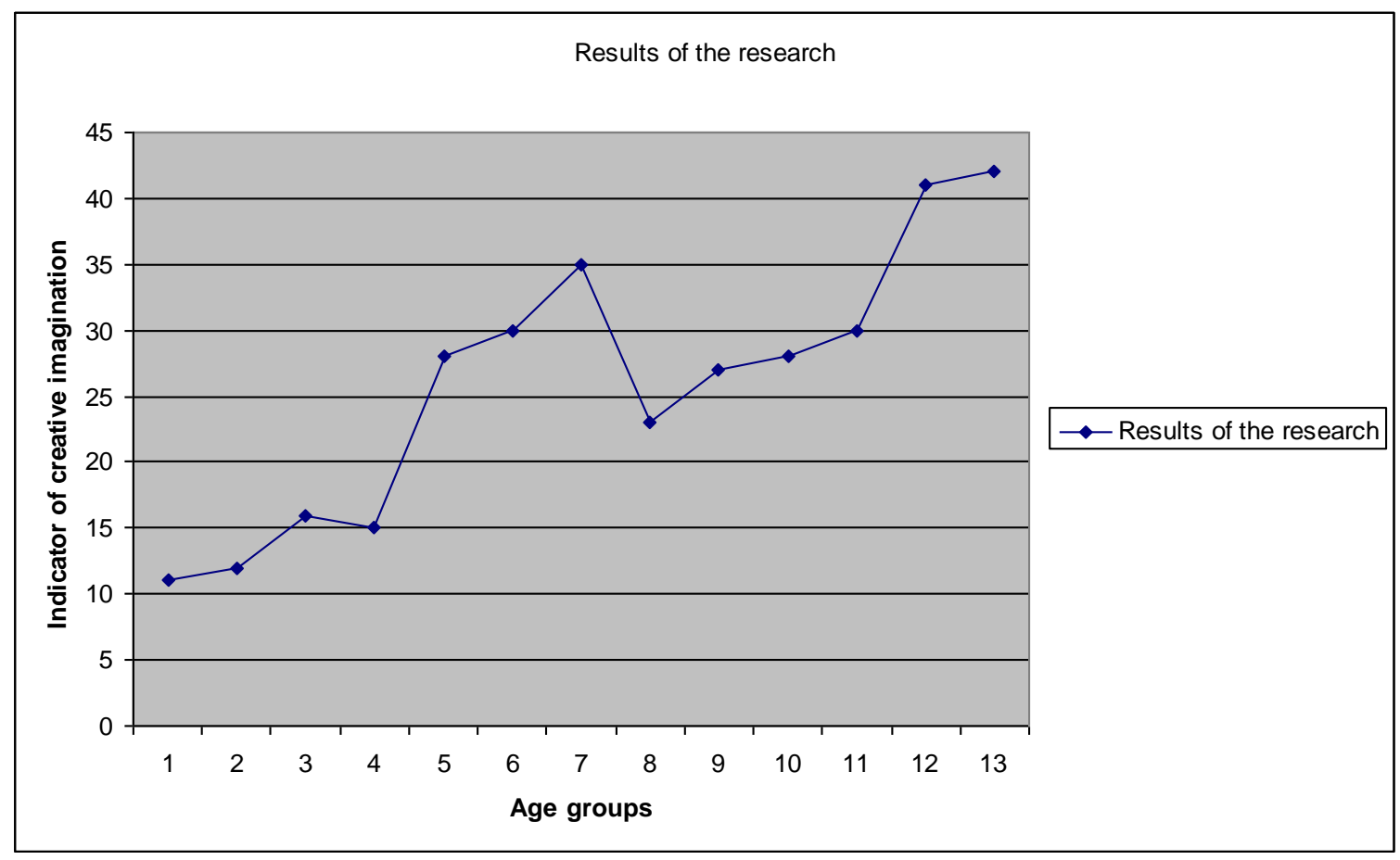

Figure 4. Results of the study about the dynamics of creative imagination.

The second delay longs from 13-14 until 29 that marks the stage of a development of teenagers and youth. This is a time pf significant changes in one's life. During this time, one develops one's professional identity (Erikson, 1995), that is needed for a solution of essential life problems: with whom to develop friendships, how to gain an authority in a referent group, where to go to study, how to choose a partner. Besides, is the age group of youth, the use of slang - a more primitive language is typical. The critical points in the development of a creative imagination relates to critical points in persons' development, related to changes in the social status and new roles of an individual.

The participants were from one region. Therefore, the conclusions made according the research findings are only tentative. Despite of the similarities of this experiment with the experiment of T. Ribot, there is a need for further investigation that requires bigger number of respondents and regions to be included. That other aspects that need to be considered are: the status of the respondents: education, social status and the regional peculiarities.

\section{Conclusions}

- Creativity plays a significant role in a sustainable development of 0-humankind. Schools need to play an essential role in developing creativity among children since children are "natural dreamers 'and they use their imagination to explore new possibilities. Conventional education prioritizes thinking as a disconnected from imagining, rational concepts become disconnected from creative thinking. Children do not use their creative abilities for thought-based exercises.

- The authors encourage schools to pay more attention to the development of creativity and we believe this is an essential ability in co-creation of sustainable solutions. Sustainability depends on one's ability to be creative and innovative. This can bring along new solutions and can help to adapt to challenging situations by developing a positive future-oriented attitude.

- As this was stated by T. Ribot, there are two crises in the development of creative imagination of an individual - at the age of 7-8 and at the age of 15-16. The results gained in this study also testifies the fact that there are two peaks in the development of this phenomenon (achieving the highest values) - at the age of 11-12 and at the age of 30-40. The educator needs to pay close attention to critical points one's development in order to capture the most sensitive time for a development of an individual's creative potential. 


\section{Bibliography}

1. Acar S., Burnett C., Cabra J.F. (2017). Ingredients of Creativity, Originality and More. In K. Egan, C. Judson and K. Madey (Eds.), Creativity Research Journal, 29 (2), 133-144.

2. Alexander G., Shoshani Y. (2015). Dialectic Explication of Creativity. Engaging Imagination and Developing Creativity in Education. UK: Cambridge Scholars Publishing, 17-32.

3. Amabile T.M. (1996). Creativity in Context: Update to the Social Psychology of Creativity. Boulder, Colorado, US: Westview Press.

4. Boden M.A. (2004). The Creative Mind: Myths and Mechanisms. ( $2^{\text {nd }}$ ed.). London: Routledge. Retrieved from https://pdfs.semanticscholar.org/52f1/53075b22469fa82ecb35099b8810e95c31f6.pdf

5. Dewey D. (1910). How we think. Boston: D.C. Health and Company. Retrieved from http://rci.rutgers.edu/ tripmcc/phil/dewey-hwt-pt1-selections.pdf

6. Erikson E.H. (1995). Childhood and Society. New York: Vintage.

7. Freud S. (1990). Leonardo da Vinci and a Memory of His Childhood. New York: WW Norton and Co.

8. Freud Z. (2011). Wit and Its Relation to the Unconscious. New York: Bartleby.com.

9. Gloveanu V.P. (2010). Creativity in Context: The Ecology of Creativity Evaluations and Practices in an Artistic Craft. Psychological studies, 55 (4), 339-350. Retrieved from https://core.ac.uk/download/pdf/221330.pdf

10. Ilisko Dz. (2007). Teachers as Agents of Societal Change. Journal of Teacher Education for Sustainability, 11(7), 14-27.

11. Jung C.G. (Ed.). (1988). Man and his symbols. San Sebastian: TONSA. Retrieved from https://monoskop.org/images/9/97/Von_Franz_Luise_Marie_Jung_Gustav_Carl_Man_and_His_Symb ols_1988.pdf

12. Kaleja-Gasparovica D. (2012). Studentu radosuma veicinasana vizualas makslas studijas (Facilitation of students' creativity in visual art studios). (Doctoral Thesis). Riga: Latvijas University. Retrieved from https://dspace.lu.lv/dspace/bitstream/handle/7/4720/22977-

Daiga_Kaleja_Gasparovica_2012.pdf?sequence $=1$ (in Latvian)

13. Kozbelt A., Beghetto R.A., Runco M.A. (2010). Theories of Creativity. In J. C. Kaufman and J. Sternberg (Eds). The Handbook of Creativity. Cambridge Handbooks of Psychology. UK: Cambridge University Press, 21-47. Retrieved from

https://static1.squarespace.com/static/52d6f16be4b0770a 479dfb9c/t/53bfc77be4b04e5d54cfb085/1405 077371508/ThryCrty\%28KozbeltBeghettoRunco\%2C2010\%29.pdf

14. Plesk P.E. (1997). Creativity, Innovation and Quality. (1 ${ }^{\text {st }}$ ed.). Milwaukee, Wisconsin: Quality Press.

15. Plucker J.A., Makel M.C. (2010). Assessment of Creativity. In. J.C. Kaufman, J. Sternberg (Eds.). The Handbook of Creativity. Cambridge Handbooks of Psychology. UK: Cambridge University Press, 48-73.

16. Rhodes M. (1961). An Analysis of Creativity. The Phi Delta Kappan, 42 (7), 305-310.

17. Ribot T. (1906). Essay on the Creative Imagination. Chicago: The open court publishing company.

18. Salite I. (2015). Searching for Sustainability in Teacher Education and Educational Research: Experiences from the Baltic and Black Sea Circle Consortium for Educational Research. Discourse and Communication for Sustainable Education, 6(1), 21-29.

19. Shlahova A., Volonte I., Cacka M. (2017). Interrelations in the Development of Primary School Learners' Creative Imagination and Creative Activity When Depicting a Portrait in Visual Art Lessons. Discourse and Communication for Sustainable Education, 8 (1), 102-121.

20. Shragina L.I. (2013). Probleмa psihologii tvorchovo ujavlenja v raboti T. Ribo „Tvorcha ujava”. (The problem of creative imagination in the work of T. Ribot "Creative Imagination"). Visnik Harkovskovo nacionalnovo universitetu. Zbirnik haukovih pracj. Serija „Psihologija” 52 (1065), 76-80. (in Ukrainian)

21. Starko A.J. (1995). Creativity in Classroom. School of Curios Delight. New York: Longman Publisher. Retrieved from http://www.artsedcollaborative.org/wp-content/uploads/2015/06/Translations-Issue4_web2.pdf

22. Sternberg R.J. (Ed.). (1988). The Nature of Creativity Contemporary Psychological Perspectives. UK: Cambridge University Press.

23. Torrance E.P. (1966). The Torrance Tests of Creative Thinking-Norms-Technical Manual Research Edition-Verbal Tests, Forms A and B- Figural Tests, Forms A and B. Princeton. New York: Personnel Press. 